\title{
Synthesis and Characterization of Organic-Inorganic Nanocomposite Poly-o-anisidine Sn(IV) Arsenophosphate: Its Analytical Applications as $\mathrm{Pb}$ (II) Ion-Selective Membrane Electrode
}

\author{
Asif Ali Khan, Umme Habiba, and Anish Khan \\ Analytical and Polymer Research Laboratory, Department of Applied Chemistry, Faculty of Engineering and Technology, \\ Aligarh Muslim University, Aligarh 202002, India \\ Correspondence should be addressed to Asif Ali Khan, asifkhan42003@yahoo.com
}

Received 9 October 2008; Revised 15 April 2009; Accepted 29 May 2009

Recommended by Jan Åke Jönsson

Poly-o-anisidine Sn(IV) arsenophosphate is a newly synthesized nanocomposite material and has been characterized on the basis of its chemical composition, ion exchange capacity, TGA-DTA, FTIR, X-RAY, SEM, and TEM studies. On the basis of distribution studies, the exchanger was found to be highly selective for lead that is an environmental pollutant. For the detection of lead in water a heterogeneous precipitate based ion-selective membrane electrode was developed by means of this composite cation exchanger as electroactive material. The membrane electrode is mechanically stable, with a quick response time, and can be operated over a wide $\mathrm{pH}$ range. The selectivity coefficients were determined by mixed solution method and revealed that the electrode is sensitive for $\mathrm{Pb}(\mathrm{II})$ in presence of interfering cations. The practical utility of this membrane electrode has been established by employing it as an indicator electrode in the potentiometric titration of $\mathrm{Pb}(\mathrm{II})$.

Copyright (C) 2009 Asif Ali Khan et al. This is an open access article distributed under the Creative Commons Attribution License, which permits unrestricted use, distribution, and reproduction in any medium, provided the original work is properly cited.

\section{Introduction}

During the last 15 years, the development of organic/ inorganic hybrid materials has been an important enterprise for people from very diverse origins (academic, research and industrial sectors). The intrinsic multifunctional character of these materials makes them potentially useful in multiple fields. Illustrative examples of this versatility are their high-added-value applications as coatings for corrosion protection and abrasion resistance, artificial membranes for ultra- and nanofiltration, pervaporation and gas separation, catalysts and nanoscopic reactors, adsorbents of toxic compounds, biomaterials for osteo-reconstructive surgery or ophthalmic, materials with specific optic, electrical and/or magnetic properties for telecommunications or information displays, and so forth. The growing interest of this subject matter has been reflected in two symposia "organized recently by the Materials Research Society [1, 2]". Most of the organic/inorganic hybrid materials are nanocomposite materials in which the inorganic part and the organic entities interact at molecular level in the nanoscopic domain. This kind of materials often present the best properties of each of its components in a synergic way, offering a unique opportunity to prepare tailor-made new materials with chemical, physical, and mechanical properties of a high performance as discussed elsewhere $[3,4]$.

The most obvious advantage of organic and inorganic hybrids is that they can favorably combine the often dissimilar properties of organic and inorganic components in one material. Hybrid materials represent one of the most fascinating developments in material chemistry in recent years. Thus efforts have been made to synthesize such hybrid ion exchangers with good ion exchange properties, high stability, reproducibility, and selectivity for heavy toxic metal ions as discussed by Khan et al. [5]. In the present research work Poly-o-anisidine Sn(IV) arsenophosphate, is a newly synthesized organic-inorganic nanocomposite material developed in our laboratory that possessed all 
such characteristics discussed earlier and is highly selective for lead, a hazardous toxic material in the environment. The material is also used in making $\mathrm{Pb}(\mathrm{II})$ ion selective membrane electrode.

\section{Experimental}

2.1. Chemicals and Reagents. The main reagents used for the synthesis were obtained from CDH, Loba Chemie, and E-Merck (India Ltd., used as received). All other reagents and chemicals were of analytical grade. The following instruments were used for various studies made for chemical analysis and characterization of the composite material: UV/VIS spectrophotometer (Elico, India), model EI 301 E; a thermal analyzer (V2.2A DuPont 9900); Elemental analyzer-Elementary Vario EL III, Carlo-Erba, model 1108; a scanning electron microscope-LEO 435 VP (Australia); FTIR spectrometer (Perkin Elmer, USA), model Spectrum BX; an X-ray diffractometer (Phillips, Holland), model PW 1148/89 with $\mathrm{Cu} \mathrm{K} \alpha$ radiations; an automatic temperature controlled water bath incubator shaker (Elcon, India); a digital potentiometer (Equiptronics EQ 609, India); accuracy $\pm 0.1 \mathrm{mV}$ with a saturated calomel electrode as reference electrode; an electronic balance (digital) (Sartorius, Japan), model 21 OS, Japan.

2.2. Preparation of Reagent Solutions. $0.1 \mathrm{molL}^{-1}$ solution of Tin tetrachloride, $\mathrm{SnCl}_{4} \cdot 5 \mathrm{H}_{2} \mathrm{O}$, and O-phosphoric acid $\left(\mathrm{H}_{3} \mathrm{PO}_{4}\right)$ were prepared in $1 \mathrm{molL}^{-1} \mathrm{HCl}$ and demineralized water (DMW), respectively. $0.1 \mathrm{molL}^{-1}$ solution of disodium arsenate, $\mathrm{Na}_{2} \mathrm{HAsO}_{4} \cdot 7 \mathrm{H}_{2} \mathrm{O}$ was prepared in DMW. $2.5 \%$ solution of orthoanisidine, $\mathrm{CH}_{3} \mathrm{OC}_{6} \mathrm{H}_{4} \mathrm{NH}_{2}$, and $0.05 \mathrm{molL}^{-1}$ solution of ammonium persulphate $\left(\mathrm{NH}_{4}\right)_{2} \mathrm{~S}_{2} \mathrm{O}_{8}$ were prepared in $1 \mathrm{molL}^{-1} \mathrm{HCl}$.

\subsection{Preparation of Poly-o-anisidine $S n(I V)$ \\ Arsenophosphate Nanocomposite}

2.3.1. Synthesis of Poly-o-anisidine. Poly-o-anisidine is oxidatively synthesized using ammonium persulphate $\left(\mathrm{NH}_{4}\right)_{2} \mathrm{~S}_{2} \mathrm{O}_{8}$ under the controlled condition as discussed by Ram et al. [6]. The organic polymer derivative of o-methoxy aniline (poly-o-anisidine) was prepared by mixing in similar volume ratios of the solution of $0.05 \mathrm{molL}^{-1}$ ammonium persulphate prepared in $1 \mathrm{molL}^{-1} \mathrm{HCl}$ and $2.5 \%$ distilled o-anisidine prepared in $1 \mathrm{molL}^{-1} \mathrm{HCl}$ with continuous stirring by a magnetic stirrer for 2 hours at $0^{\circ} \mathrm{C}$. A green colored gel was obtained. The gel was kept for 24 hours at room temperature.

2.3.2. Synthesis of $\operatorname{Sn}(I V)$ Arsenophosphate. The inorganic precipitate of $\mathrm{Sn}(\mathrm{IV})$ arsenophosphate ion-exchanger was prepared at room temperature $\left(25 \pm 2{ }^{\circ} \mathrm{C}\right)$ by mixing an aqueous solution of $0.1 \mathrm{molL}^{-1} \mathrm{o}$-phosphoric acid $\left(\mathrm{H}_{3} \mathrm{PO}_{4}\right)$ to aqueous solutions of $0.1 \mathrm{molL}^{-1}$ disodium arsenate $\left(\mathrm{Na}_{2} \mathrm{HAsO}_{4} \cdot 7 \mathrm{H}_{2} \mathrm{O}\right)$ and $0.1 \mathrm{molL}^{-1}$ Tin tetrachloride in $1 \mathrm{molL}^{-1} \mathrm{HCl}$ in different mixing volume ratios as discussed by Niwas et al. [7]. The white precipitates were obtained, when the $\mathrm{pH}$ of the mixtures was adjusted to $\sim 1$ by adding aqueous ammonia with constant stirring.

2.3.3. Synthesis of Poly-o-anisidine Sn(IV) Arsenophosphate. The composite cation-exchanger was prepared by the solgel mixing of poly-o-anisidine, an organic polymer, into the inorganic precipitate of $\mathrm{Sn}(\mathrm{IV})$ arsenophosphate. In this process, when the gel of poly-o-anisidine were added to the white inorganic precipitate of Sn(IV) arsenophosphate with a constant stirring, the resultant mixture was turned slowly into a black colored slurries. The resultant black colored slurries were kept for 24 hours at room temperature $(25 \pm$ $\left.2{ }^{\circ} \mathrm{C}\right)$. Now the poly-o-anisidine-based composite cationexchanger gels were filtered off, washed thoroughly with DMW to remove excess acid and any adhering trace of ammonium persulphate. The washed gels were dried over $\mathrm{P}_{4} \mathrm{O}_{10}$ at $45^{\circ} \mathrm{C}$ in an oven. The dried products were immersed in DMW to obtain small granules. They were converted to the $\mathrm{H}^{+}$form by keeping it in $1 \mathrm{molL}^{-1} \mathrm{HNO}_{3}$ solution for 24 hours with occasional shaking intermittently replacing the supernatant liquid. The excess acid was removed after several washing with DMW. The materials were finally dried at $40^{\circ} \mathrm{C}$ and sieved to obtain particles of particular size range $(\sim 125 \mu \mathrm{m})$. Hence a number of poly-o-anisidine $\operatorname{Sn}(1 \mathrm{~V})$ arsenophosphate nanocomposite cation-exchanger samples were prepared, and on the basis of $\mathrm{Na}^{+}$exchange capacity (I.E.C), percent of yield, and physical appearance, sample (S9) was selected for further studies.

2.4. Chemical Composition. The chemical composition of poly-o-anisidine $\mathrm{Sn}(\mathrm{IV})$ arsenophosphate composite cation exchanger (S-9) was determined by using elemental analyzer, inductively coupled plasma mass spectrophotometer and $\mathrm{UV}$-visible spectrophotometer for $\mathrm{CHN}, \mathrm{As}, \mathrm{Sn}$, and $\mathrm{P}$.

2.5. Scanning Electron Microscopy (SEM) Studies. Microphotographs of the original form of poly-o-anisidine (S$5)$, inorganic precipitate of $\operatorname{Sn}(\mathrm{IV})$ arsenophosphate (S-1), and organic-inorganic composite material poly-o-anisidine $\mathrm{Sn}(\mathrm{IV})$ arsenophosphate (S-9) were obtained by the scanning electron microscope at various magnifications.

2.6. X-Ray Analysis. Powder X-ray diffraction (XRD) pattern was obtained in an aluminum sample holder for polyo-anisidine $\mathrm{Sn}(\mathrm{IV})$ arsenophosphate (S-9) in the original form using a PW, 1148/89-based diffractometer with $\mathrm{Cu} \mathrm{K} \alpha$ radiations.

2.7. Fourier Transform Infra Red (FTIR) Studies. The FTIR spectrum of poly-o-anisidine (S-5), Sn(IV) arsenophosphate (S-1), and poly-o-anisidine $\mathrm{Sn}(\mathrm{IV})$ arsenophosphate (S-9), dried at $40^{\circ} \mathrm{C}$, were taken by $\mathrm{KBr}$ disc method at room temperature.

2.8. Thermal (TGA and DTA) Studies. Simultaneous TGA and DTA studies of the composite cation-exchange material poly-o-anisidine Sn(IV) arsenophosphate (S-9) in original form were carried out by an automatic thermo balance on 
heating the material from $10^{\circ} \mathrm{C}$ to $1000^{\circ} \mathrm{C}$ at a constant rate $\left(10^{\circ} \mathrm{C}\right.$ per minute) in the air atmosphere (air flow rate of $200 \mathrm{~mL} \mathrm{~min}^{-1}$ ).

2.9. Transmission Electron Microscopy (TEM) Studies. Microphotographs of the composite material poly-oanisidine Sn(IV) arsenophosphate (S-9) were obtained by the transmission electron microscope at various magnifications.

2.10. Selectivity (Sorption) Studies. The distribution coefficients ( $K_{d}$ values) of various metal ions on poly-o-anisidine $\mathrm{Sn}(\mathrm{IV})$ arsenophosphate composite were determined by batch method in various solvent systems. Various $200 \mathrm{mg}$ portions of the composite cation-exchanger beads (S-9) in the $\mathrm{H}^{+}$form were taken in Erlenmeyer flasks with $20 \mathrm{~mL}$ of different metal nitrate solutions in the required medium and kept for 24 hours with continuous shaking hours in a temperature controlled incubator shaker at $25 \pm 2{ }^{\circ} \mathrm{C}$ to attain equilibrium. The initial metal ion concentration was so adjusted that it did not exceed 3\% of its total ion exchange capacity. The metal ions in the solution before and after equilibrium were determined by titrating against standard $0.005 \mathrm{molL}^{-1}$ solution of EDTA as discussed by Reiliy et al. [8]. The alkali and alkaline earth metal ions $\left[\mathrm{K}^{+}, \mathrm{Na}^{+}, \mathrm{Ca}^{2+}\right]$ were determined by flame photometry, and some heavy metal ions such as $\left[\mathrm{Pb}^{2+}, \mathrm{Cd}^{2+}, \mathrm{Cu}^{2+}, \mathrm{Hg}^{2+}, \mathrm{Ni}^{2+}, \mathrm{Mn}^{2+}, \mathrm{Zn}^{2+}\right]$ were determined by atomic absorption spectrophotometry (AAS). The distribution quantity is the ratio of the amount of metal ions in the exchanger phase and in the solution phase. In other words, the distribution coefficient is the measure of a fractional uptake of metal ions competing for $\mathrm{H}^{+}$ions from a solution by an ion-exchange material and hence mathematically can be calculated using the formula given as

$$
K_{d}=\frac{\mathrm{m} \text { moles of metal ions } / \mathrm{gm} \text { of ion-exchanger }}{\mathrm{m} \text { moles of metal ions } / \mathrm{mL} \text { of solution }}\left(\mathrm{mLg}^{-1}\right) \text {, }
$$

that is,

$$
K_{d}=\left[\frac{I-F}{F}\right] \times \frac{V}{M}\left(\mathrm{~mL} \mathrm{~g}^{-1}\right)
$$

where $I$ is the initial amount of metal ion in the aqueous phase, $F$ is the final amount of metal ion in the aqueous phase, $V$ is the volume of the solution $(\mathrm{mL})$, and $M$ is the amount of cation-exchanger $(\mathrm{g})$.

\subsection{Preparation of Poly-o-anisidine Sn(IV) Arsenophosphate} Cation Exchange Membrane. The ion exchange membrane of poly-o-anisidine $\mathrm{Sn}(\mathrm{IV})$ arsenophosphate was prepared as discussed by Khan et al. [5] in earlier studies. To find out the optimum membrane composition, a different amount of the composite material was grounded to a fine powder and mixed thoroughly with a fixed amount $(200 \mathrm{mg})$ of PVC in $10 \mathrm{~mL}$ tetrahydrofuran and 10 drops of dioctylphthalate. The resultant slurries were poured to cast in glass tubes of $10 \mathrm{~cm}$ in length and $5 \mathrm{~mm}$ in diameter. These glass tubes were left for slow evaporation for 24 hours. In this way four sheets of different thicknesses $(0.2,0.28,0.3$, and 0.4$) \mathrm{mm}$ were obtained. These sheets were cut in the shapes of discs using a sharp edge blade for further studies.

2.12. Characterization of Membrane. Physicochemical characterization is important to understand the performance of membrane. Thus some parameters such as porosity, water content, swelling, and thickness were determined as described elsewhere [9-13].

2.12.1. Water Content (\% Total Wet Weight). First, the membranes were soaked into water to elute diffusible salt, blotted quickly with Whatmann filter paper to remove surface moisture and immediately weighed. These were further dried to a constant weight in a vacuum over $\mathrm{P}_{2} \mathrm{O}_{5}$ for 24 hours. The water content (total wet weight) was calculated as

$$
\% \text { Total wet weight }=\frac{W_{w}-W_{d}}{W_{w}} \times 100,
$$

where $W_{w}$ is the weight of the soaked/wet membrane, and $W_{d}$ is the weight of the dry membrane.

2.12.2. Porosity. The thickness of the membrane was measured by taking the average thickness of the membrane by using screw gauze. Swelling is measured as the difference between the average thicknesses of the membrane equilibrated with $1 \mathrm{molL}^{-1} \mathrm{NaCl}$ for 24 hours and the dry membrane:

$$
\text { Porosity }=\frac{W_{w}-W_{d}}{W_{w} \rho_{0} L A},
$$

where $W_{w}$ and $W_{d}$ are weight of wet/soaked membrane, $\rho_{0}$ is the density of water, while $A$ and $L$ are the area and thickness of the membrane.

2.12.3. Thickness and Swelling. The thickness of the membrane was measured by taking the average thickness of the membrane by using screw gauze. Swelling is measured as the difference between the average thickness of the membrane equilibrated with $1 \mathrm{molL}^{-1} \mathrm{NaCl}$ for 24 hours and the dry membrane.

2.13. Fabrication of Ion-Selective Membrane Electrode. The membrane sheet of $0.3 \mathrm{~mm}$ thickness as obtained by the above procedure was cut in the shape of disc and mounted at the lower end of a Pyrex glass tube (o.d. $0.8 \mathrm{~cm}$, i.d. 0.6) with araldite. Finally the assembly was allowed to dry in air for 24 hours. The glass tube was filled with $0.1 \mathrm{molL}^{-1}$ lead nitrate solution. A saturated calomel electrode was inserted in the tube for electrical contact, and another saturated calomel electrode was used as external reference electrode. The whole arrangement can be shown in Table 1 .

Following parameters were evaluated to study the characteristics of the electrode such as lower detection limit, electrode response curve, response time, and working $\mathrm{pH}$ range. 
TABLE 1

\begin{tabular}{|c|c|c|c|c|}
\hline $\begin{array}{l}\text { Internal } \\
\text { reference } \\
\text { electrode } \\
\text { (SCE) }\end{array}$ & $\begin{array}{l}\text { Internal } \\
\text { electrolyte } \\
0.1 \mathrm{M} \\
\mathrm{Pb}^{2+}\end{array}$ & Membrane & $\begin{array}{l}\text { Sample } \\
\text { solution }\end{array}$ & $\begin{array}{l}\text { External } \\
\text { reference } \\
\text { electrode } \\
\text { (SCE) }\end{array}$ \\
\hline
\end{tabular}

2.14. Electrode Response or Membrane Potential. To determine the electrode response, a series of standard solutions to be studied of varying concentrations were prepared. External electrode and ion selective membrane electrode are plugged in digital potentiometer, and the potentials were recorded.

For the determination of electrode potentials the membrane of the electrode was conditioned by soaking in $0.1 \mathrm{molL}^{-1} \mathrm{~Pb}\left(\mathrm{NO}_{3}\right)_{2}$ solution for 5-7 days and for 1 hour before use. When electrode was not in use electrode must be kept in $0.1 \mathrm{molL}^{-1}$ selective ion solution. Potential measurement was plotted against selected concentration of the respective ion in aqueous solution.

2.15. Effect of $p H$. A series of solutions of varying $\mathrm{pH}$ in the range of $1-11$ were prepared, keeping the concentration of the relevant ion constant $\left(1 \times 10^{-2} \mathrm{molL}^{-1}\right)$. The value of electrode potential at each $\mathrm{pH}$ was recorded, and plot of electrode potential versus $\mathrm{pH}$ was plotted.

2.16. The Response Time. The method of determining response time in the present work is being outlined as follows. The electrode is first dipped in a $1 \times 10^{-3} \mathrm{molL}^{-1}$ solution of the ion concerned and immediately shifted to another solution of $1 \times 10^{-2} \mathrm{molL}^{-1}$ ion concentration of the same ion (10 fold higher concentrations), and the solutions were continuously been stirred. The potential of the solution was read at zero second, just after dipping of the electrode in the second solution and subsequently recorded at the intervals of 5 seconds. The potentials were then plotted versus the time. The time during which the potentials attain constant value represents the response time of the electrode.

2.17. Selectivity Coefficient. To study the cationic interference due to other ions, the selectivity coefficients of various interfering cations for the ion-selective membrane electrode were determined by the mixed solution method as discussed elsewhere $[9,10]$. A beaker of constant volume contains a mixed solution having a fixed concentration of interfering ion $\left(\mathrm{M}^{\mathrm{n}+}\right)\left(1 \times 10^{-2} \mathrm{molL}^{-1}\right)$ and varying concentrations $\left(1 \times 10^{-1}\right.$ to $\left.1 \times 10^{-10} \mathrm{molL}^{-1}\right)$ of the primary ions. Now the potential measurements were made using the membrane electrode assembly.

\section{Results and Discussion}

Poly-o-anisidine was synthesized by chemical oxidation using ammonium persulfate (APS) in $1 \mathrm{molL}^{-1} \mathrm{HCl}$ aqueous solution as discussed by Koval'chuk et al. [14]. The electron transfer phenomenon is considered as follows:

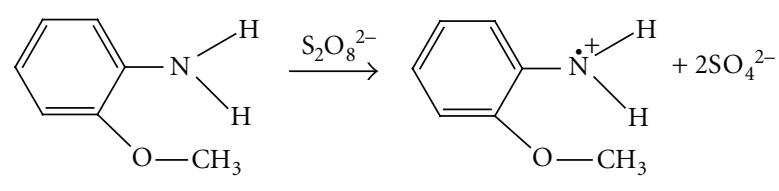

(I)

Deprotonation of the primary cation radical can take place:

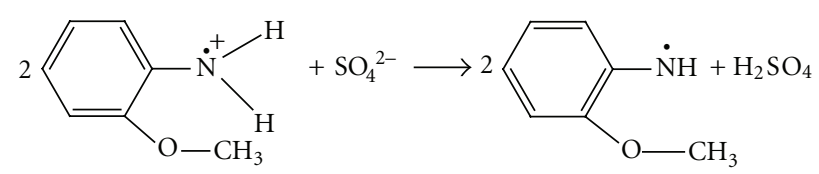

(II)

The "head-to-tail" formation of polymer can happen only when the isomerisation of the nitrenium radicals to quinoid structure (III) takes place:
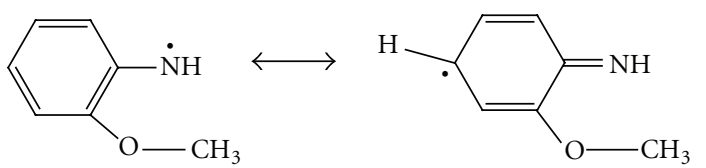

(III)

The isomerisation of the o-anisidine occurs easily, while this process for the $\mathrm{p}$-isomer is more complicated. The formation of the N-N bond takes place when dimer is formed by the head-to-head recombination of the two primary radicals. In this case the further chain propagation is impossible. The polymer formation proceeds through the interaction of primary formed and isomerized radicals and further through the oxidation of generated dimmers:

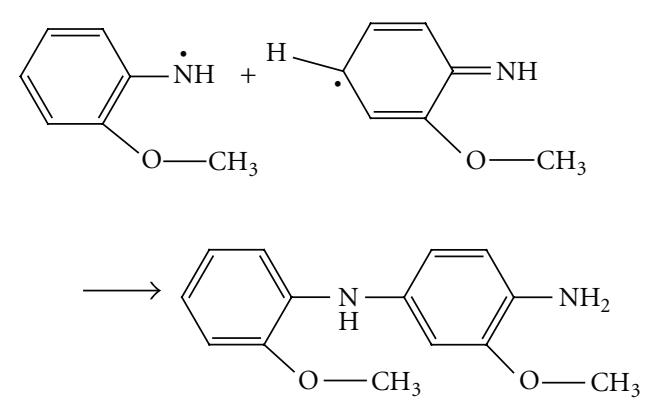

In this case, it is assumed that transition of the quinoid structure into the link of benzoid type reisomerization takes place. For example, the trimer formation is possible as a result of the recombination of oxidized dimer and initial isomerised radical according to 

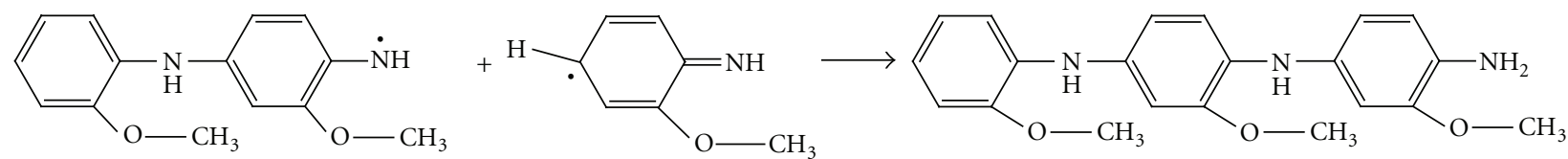

This process can be defined as an oxidative polycondensation since the main-chain link and the molecule of initial monomer are not identical. Such propagation of polymer chains as a result of recombination of oligomeric species with the initial monomeric ones leads to the fast monomer consumption, as discussed elsewhere [15] during the oxidation of aniline in $\left(\mathrm{NH}_{4}\right)_{2} \cdot \mathrm{S}_{2} \mathrm{O}_{8}$ in aqueous solution. The formation of inorganic precipitate of Sn(IV) arsenophosphate was significantly affected by the $\mathrm{pH}$, and the most favorable $\mathrm{pH}$ of the mixture was $\sim 1.0$. The binding of poly-o-anisidine into the matrix of Sn(IV) arsenophosphate (assumed as $\mathrm{X}$ in the reaction) can be given as

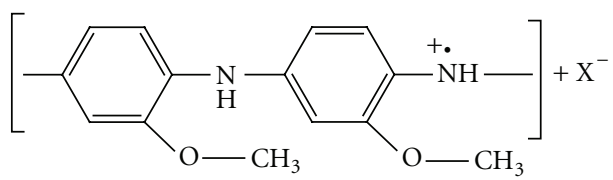

Poly-o-anisidine $\quad \mathrm{Sn}(\mathrm{IV})$ arsenophosphate

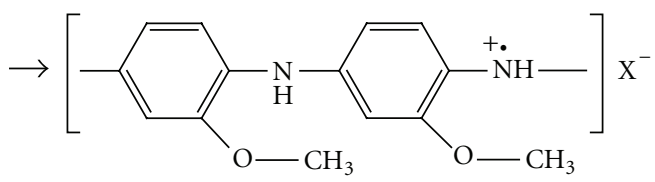

Poly-o-anisidine Sn(IV) arsenophosphate

Various samples of organic-inorganic composite cation exchange material have been developed by the incorporation of electrically conducting polymer poly-o-anisidine into the inorganic matrices of granular Sn(IV) arsenophosphate. Due to high percentage of yield, better ion exchange capacity, reproducible behavior, and chemical and thermal stability, sample (S-9) in Table 2 was chosen for detailed studies. The percent composition of $\mathrm{C}, \mathrm{H}, \mathrm{N}, \mathrm{O}, \mathrm{Sn}, \mathrm{P}$, and As in the material was found to be $10.44,1.8,1.74,35.79,7.38,5.59$, and 37.25 , respectively.

The scanning electron microphotographs of poly-oanisidine (a), Sn(IV) arsenophosphate (b), and poly-oanisidine Sn(IV) arsenophosphate (c) are given in Figure 1. It is clear from the photographs that after binding of organic polymer with inorganic precipitate of Sn(IV), arsenophosphate morphology has been changed, which indicates the formation of organic-inorganic composite cation exchanger poly-o-anisidine $\mathrm{Sn}(\mathrm{IV})$ arsenophosphate. The X-ray diffraction pattern of poly-o-anisidine Sn(IV) arsenophosphate cation exchange material (S-9) recorded in powdered sample exhibited some small peaks in the spectrum in Figure 2. It is clear from the figure that the nature of composite cation exchange material is semicrystalline.

The IR peaks observed at $3421,540,587,843,1020$, 1115,1296 , and $1590 \mathrm{~cm}^{-1}$ are the characteristic bands for

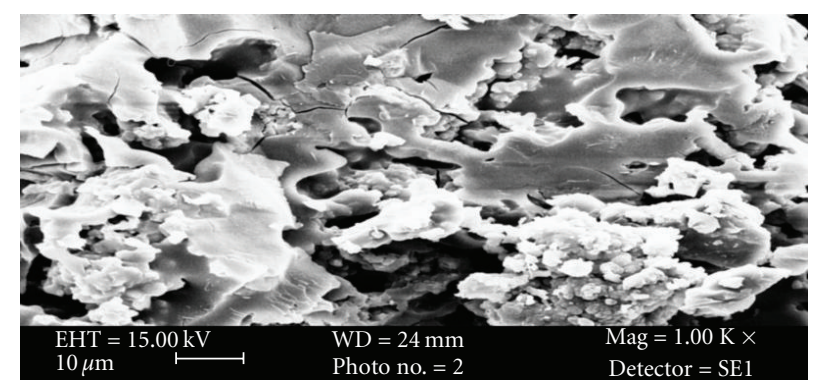

(a)

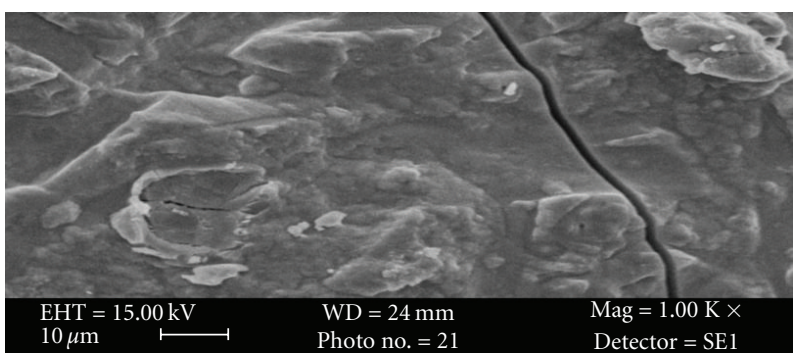

(b)

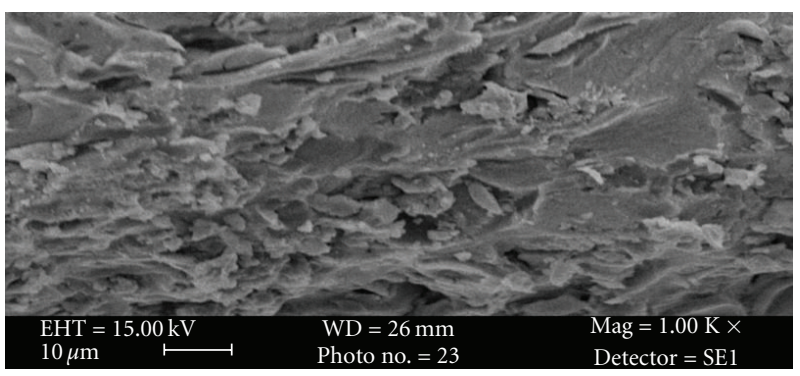

(c)

FIGURE 1: SEM photographs of poly-o-anisidine (a), Sn(IV) arsenophosphate (b) and poly-o-anisidine Sn(IV) arsenophosphate (c) cation exchangers.

Poly-o-anisidine Sn(IV) arsenophosphate composite cation exchanger (S-9) in Figure 3. A broad band at $\sim 3421 \mathrm{~cm}^{-1}$ is due to the $\mathrm{N}-\mathrm{H}$ stretching mode. The band at $1020 \mathrm{~cm}^{-1}$ is due to the orthosubstituted aromatic ring. Band stretching at 1590 and $1296 \mathrm{~cm}^{-1}$ shows the presence of $\mathrm{C}-\mathrm{N}$ and $\mathrm{C}=\mathrm{N}$ linkage as discussed by Ram et al. [6]. The band at $\sim 1115 \mathrm{~cm}^{-1}$ is attributed to a plane bending vibration of $\mathrm{C}-\mathrm{H}$ which is formed during protonation of benzene ring. The two peaks at 587 and $540 \mathrm{~cm}^{-1}$ and a peak at 843 indicate the $\mathrm{M}-\mathrm{O}$ bonding and $\mathrm{Sn}-\mathrm{O}$ bonding as discussed by D. K. Singh and S. Singh [16]. 
TABLE 2: Conditions of preparation and the ion exchange capacity of poly-o-anisidine $\mathrm{Sn}(\mathrm{IV})$ arsenophosphate composite cation exchanger.

\begin{tabular}{|c|c|c|c|c|c|c|c|c|}
\hline \multirow[t]{2}{*}{ Sample } & \multicolumn{3}{|c|}{ Mixing volume ratios (v/v) } & \multirow{2}{*}{$\begin{array}{l}\mathrm{pH} \text { of the } \\
\text { inorganic } \\
\text { ion } \\
\text { exchanger }\end{array}$} & \multicolumn{2}{|c|}{ Mixing volume ratios (v/v) } & \multirow{2}{*}{$\begin{array}{l}\text { Appearance } \\
\text { of the } \\
\text { samples }\end{array}$} & \multirow{2}{*}{$\begin{array}{l}\text { Ion } \\
\text { exchange } \\
\text { capacity in } \\
\text { meq/g }\end{array}$} \\
\hline & $\begin{array}{l}0.1 \mathrm{molL}^{-1} \\
\mathrm{Na}_{2} \mathrm{HAsO}_{4} \\
\text { in DMW }\end{array}$ & $\begin{array}{l}0.1 \mathrm{molL}^{-1} \\
\mathrm{SnCl}_{4} \cdot 5 \mathrm{H}_{2} \mathrm{O} \\
\text { in } 1 \mathrm{molL}^{-1} \mathrm{HCl}\end{array}$ & $\begin{array}{l}0.1 \mathrm{molL}^{-1} \\
\mathrm{H}_{3} \mathrm{PO}_{4} \text { in } \\
\text { DMW }\end{array}$ & & $\begin{array}{l}2.5 \% \\
\mathrm{CH}_{3} \mathrm{OC}_{6} \mathrm{H}_{4} \mathrm{NH}_{2} \\
\text { in } 1 \mathrm{molL}^{-1} \mathrm{HCl}\end{array}$ & $\begin{array}{l}0.05 \mathrm{M} \\
\left(\mathrm{NH}_{4}\right)_{2} \mathrm{~S}_{2} \mathrm{O}_{8} \\
\text { in } 1 \mathrm{molL}^{-1} \mathrm{HCl}\end{array}$ & & \\
\hline S-1 & 1 & 1 & 1 & 1 & - & - & $\begin{array}{l}\text { white } \\
\text { granular }\end{array}$ & 0.9 \\
\hline S-2 & 1 & 1 & 1 & 1 & 1 & 1 & $\begin{array}{l}\text { Blackish } \\
\text { granular }\end{array}$ & 0.99 \\
\hline S-3 & 1 & 1 & 2 & 1 & 1 & 1 & $\begin{array}{l}\text { Blackish } \\
\text { granular }\end{array}$ & 0.72 \\
\hline S-4 & 1.5 & 0.5 & 2 & 1 & 1 & 1 & $\begin{array}{l}\text { Blackish } \\
\text { granular }\end{array}$ & 0.45 \\
\hline S-5 & - & - & - & & 1 & 1 & Black powder & 0.19 \\
\hline S-6 & 1 & 1 & 0.5 & 1 & 1 & 1 & $\begin{array}{l}\text { Blackish } \\
\text { granular }\end{array}$ & 0.5 \\
\hline S-7 & 1 & 1 & 0.5 & 1 & 1 & 1 & $\begin{array}{l}\text { Blackish } \\
\text { granular }\end{array}$ & 1.24 \\
\hline S-8 & 0.5 & 0.5 & 1 & 1 & 1 & 1 & $\begin{array}{l}\text { Blackish } \\
\text { granular }\end{array}$ & 1.2 \\
\hline S-9 & 1 & 1 & $\begin{array}{l}0.5 \\
\left(2 \mathrm{molL}^{-1}\right)\end{array}$ & 1 & 1 & 1 & $\begin{array}{l}\text { Blackish } \\
\text { granular }\end{array}$ & 1.82 \\
\hline S-10 & 0.5 & 0.5 & $\begin{array}{l}1(2 \\
\left.\mathrm{molL}^{-1}\right)\end{array}$ & 1 & 1 & 1 & $\begin{array}{l}\text { Blackish } \\
\text { granular }\end{array}$ & 0.52 \\
\hline
\end{tabular}

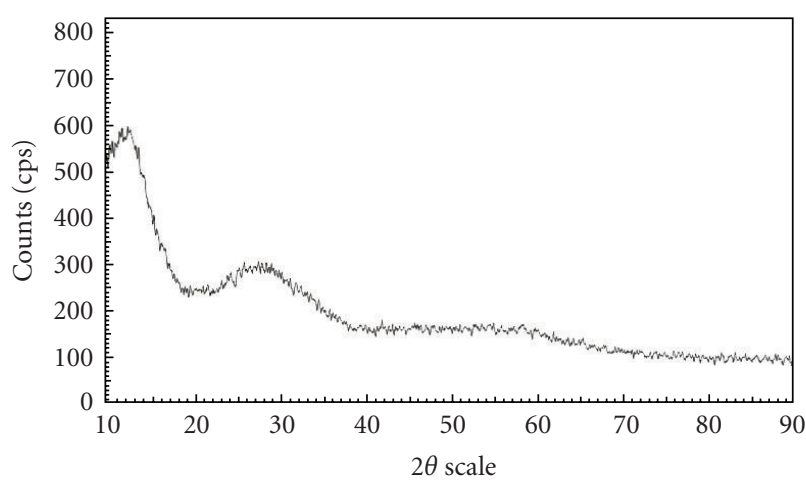

Figure 2: Powder X-ray diffraction pattern of poly-o-nisidine $\mathrm{Sn}(\mathrm{IV})$ arsenophosphate composite cation exchanger.

The thermogravimetric analysis curve of poly-oanisidine Sn(IV) arsenophosphate composite material (S-9) shows fast weight loss $(9.05 \%)$ up to $100^{\circ} \mathrm{C}$ due to the removal of external water molecules as discussed elsewhere $[17,18]$. Slow weight loss of the material from $150^{\circ} \mathrm{C}$ to about $400^{\circ} \mathrm{C}$ may be due to the formation of pyrophosphate groups by the condensation of phosphate. Further, inclination point was observed at about $550^{\circ} \mathrm{C}$ which indicates the complete decomposition of the material and the formation of metal oxides. From about $600^{\circ} \mathrm{C}$ to $900^{\circ} \mathrm{C}$, a sharp weight loss indicated by the curve may be due to the decomposition of the metal oxides. The DTA curves at 100,550 , and $1000^{\circ} \mathrm{C}$ show the exothermic decomposition reaction during the weight loss (Figure 4 ).

The transmission electron microphotographs of the composite material poly-o-anisidine Sn(IV) arsenophosphate (Figure 5) indicates that the particle size of the material is under nanorange. Thus the material is a nanocomposite material.

In order to explore the potentiality of the present composite material (S-9) in the separation of metal ions, distribution studies for 15 metal ions were performed in 15 solvent systems observed from the data given in Table 3 that the $K_{d}$-values vary with the composition and nature of the contacting solvents. Also it was found that $\mathrm{Pb}^{2+}$ was strongly adsorbed while $\mathrm{Cu}^{2+}, \mathrm{Ca}^{2+}, \mathrm{Ba}^{2+}$, and $\mathrm{Th}^{2+}$ were partially adsorbed on the surface of the ion exchanger. Thus, the studies showed that the material was found to be highly selective for $\mathrm{Pb}(\mathrm{II})$, which is an important environmental pollutant. In this work, nanocomposite poly-o-anisidine $\mathrm{Sn}(\mathrm{IV})$ arsenophosphate was also used for the preparation of heterogeneous ion-selective membrane electrode.

Sensitivity and selectivity of the ion-selective electrodes depend upon the nature of electroactive material, membrane composition, and physicochemical properties of the membranes employed. A number of samples of the polyo-anisidine Sn(IV) arsenophosphate composite membranes were prepared with different amounts of composite and fixed amount (200 mg) of PVC and checked for the mechanical 
TABLE 3: $\mathrm{K}_{d}$-values of some metal ions on poly-o-anisidine $\mathrm{Sn}(\mathrm{IV})$ arsenophosphate composite cation exchanger in different solvent systems.

\begin{tabular}{|c|c|c|c|c|c|c|c|c|c|c|c|c|c|c|c|}
\hline \multirow{2}{*}{ Solvents } & \multicolumn{15}{|c|}{ Metal ions } \\
\hline & $\mathrm{Sr}^{2+}$ & $\mathrm{Ba}^{2+}$ & $\mathrm{Pb}^{2+}$ & $\mathrm{Ca}^{2+}$ & $\mathrm{Hg}^{2}+$ & $\mathrm{Mg}^{2+}$ & $\mathrm{Th}^{4+}$ & $\mathrm{Cu}^{2+}$ & $\mathrm{Cd}^{4+}$ & $\mathrm{Ni}^{2+}$ & $\mathrm{Cr}^{3+}$ & $\mathrm{Al}^{3+}$ & $\mathrm{Fe}^{2+}$ & $\mathrm{Ce}^{3+}$ & $\mathrm{Co}^{4+}$ \\
\hline DMW & 172 & 26 & 400 & 32 & 60 & 88 & 165 & 139 & 271 & 100 & 200 & 38 & 50 & 250 & 66 \\
\hline $0.1 \mathrm{molL}^{-1} \mathrm{HCl}$ & 29 & 63 & 200 & 48 & 44 & 23 & 100 & - & 27 & 67 & 200 & 83 & 114 & - & 20 \\
\hline $0.01 \mathrm{molL}^{-1} \mathrm{HCl}$ & 54 & 122 & 766 & 112 & 44 & 38 & 38 & 543 & 59 & 15 & 67 & 29 & 29 & 322 & 85 \\
\hline $0.001 \mathrm{molL}^{-1} \mathrm{HCl}$ & 53 & 300 & 600 & 105 & 291 & 103 & 86 & 356 & 125 & 300 & 200 & - & 300 & 22 & 84 \\
\hline $0.1 \mathrm{molL}^{-1} \mathrm{HNO}_{3}$ & 23 & 88 & - & 187 & 35 & 29 & 103 & 30 & 57 & 114 & 250 & 100 & - & - & - \\
\hline $0.01 \mathrm{molL}^{-1} \mathrm{HNO} 3$ & 36 & 50 & 571 & 258 & 222 & 12 & 230 & 217 & 57 & 118 & 33 & 60 & 100 & 292 & 42 \\
\hline $0.001 \mathrm{molL}^{-1} \mathrm{HNO}_{3}$ & 26 & 27 & 187 & 136 & 333 & 3 & 55 & 67 & 18 & 86 & 39 & 250 & 114 & 483 & 59 \\
\hline $10 \%$ Formic acid & 63 & - & 767 & 80 & 222 & 37 & 55 & 167 & 20 & 22 & 93 & 60 & 450 & - & 29 \\
\hline $20 \%$ Acetone & 178 & 575 & 733 & 189 & 11 & 30 & 74 & 367 & 137 & 267 & 29 & 19 & 800 & 657 & 8 \\
\hline $0.1 \mathrm{molL}^{-1} \quad \mathrm{H}_{2} \mathrm{SO}_{4}$ & - & 25 & 33 & 91 & 169 & 55 & - & 11 & - & - & 86 & 29 & - & - & - \\
\hline $0.01 \mathrm{molL}^{-1} \quad \mathrm{H}_{2} \mathrm{SO}_{4}$ & 11 & 171 & 556 & 136 & 500 & 26 & 96 & 74 & 181 & 33 & 67 & 48 & 86 & 517 & 186 \\
\hline $10 \%$ Ethanol & 126 & 250 & 1250 & 256 & - & 75 & 50 & 340 & 650 & 38 & 33 & 10 & 200 & 500 & 36 \\
\hline Buffer 10 & 59 & 133 & 70 & 60 & 93 & 850 & - & 84 & - & - & 67 & 59 & 145 & - & - \\
\hline $0.1 \mathrm{molL}^{-1} \mathrm{KCl}$ & 57 & - & 800 & 145 & - & 49 & 14 & 164 & 69 & - & 100 & 48 & 200 & 128 & 28 \\
\hline $\mathrm{Ph} 5.75$ & 152 & 200 & 140 & 371 & - & 173 & 152 & 215 & 1033 & - & - & 280 & 86 & - & 34 \\
\hline
\end{tabular}

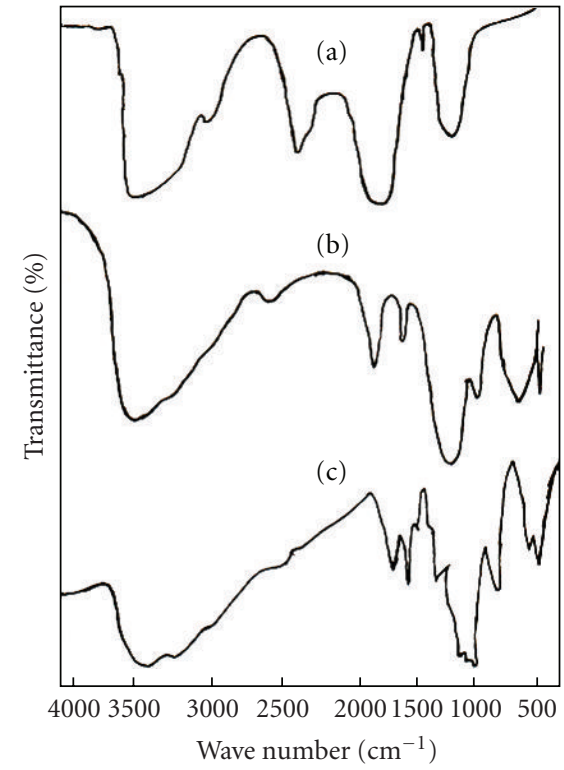

FIGURE 3: FTIR spectra of poly-o-anisidine (a) Sn(IV) arsenophosphate (b) and poly-o-anisidine Sn(IV) arsenophosphate composite cation exchanger (c).

stability, surface uniformity, materials distribution, cracks and thickness, and so forth.

The results of thickness, swelling, porosity, and water content capacity of poly-o-anisidine Sn(IV) arsenophosphate composite cation exchange membrane are summarized in Table 4. The membrane sample M-3 (thickness $0.3 \mathrm{~mm}$ ) was selected for further studies. Thus low order of water content, swelling, and porosity with less thickness of this

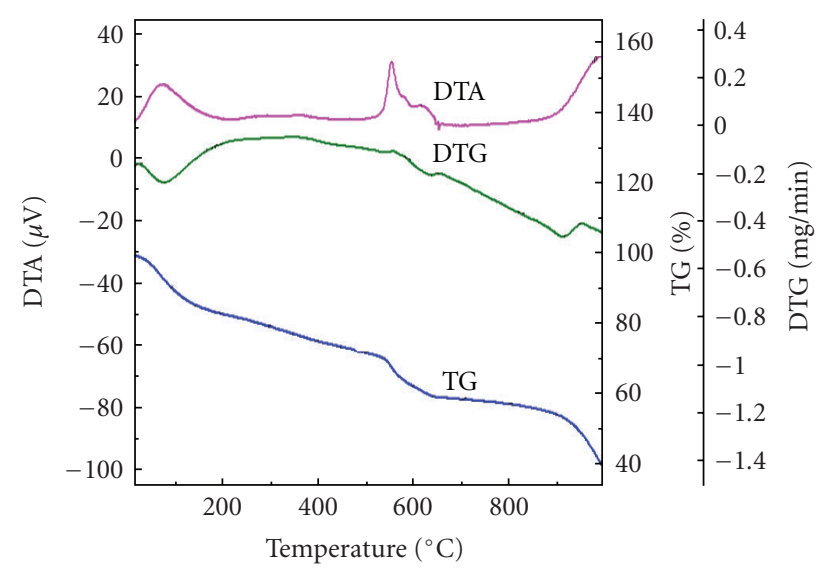

Figure 4: Simultaneous TGA-DTA curves of poly-o-anisidine $\mathrm{Sn}(\mathrm{IV})$ arsernophosphate composite cation exchanger.

membrane suggests that interstices are negligible, and diffusion across the membrane would occur mainly through the exchanger sites.

The heterogeneous precipitate $\mathrm{pb}(\mathrm{II})$ ion selective membrane electrode obtained from poly-o-anisidine Sn(IV) arsenophosphate nanocomposite material gives linear response in the range $1 \times 10^{-1} \mathrm{molL}^{-1}$ and $1 \times 10^{-6} \mathrm{molL}^{-1}$ Figure 6. Suitable concentrations were chosen for sloping portion of the linear curve, and the slope value is found to be $32.8 \mathrm{mV}$. The limit of detection is determined from the intersection of the two extrapolated segments of the calibration graph as discussed elsewhere [19], it was found to be $1 \times 10^{-6} \mathrm{molL}^{-1}$, and thus the working concentration range is found to be $1 \times 10^{-1} \mathrm{molL}^{-1}$ to $1 \times 10^{-6} \mathrm{molL}^{-1}$ for $\mathrm{Pb}^{2+}$ ions. Below $1 \times 10^{-6} \mathrm{molL}^{-1}$ non linear response 
TABLE 4: Characterization of ion exchange membranes of poly-o-anisidine $\mathrm{Sn}(\mathrm{IV})$ arsenophosphate.

\begin{tabular}{lllll}
\hline $\begin{array}{l}\text { Poly-o-anisidine } \mathrm{Sn}(\mathrm{IV}) \\
\text { arseno phosphate } \\
\text { composite material }\end{array}$ & $\begin{array}{l}\text { Thickness of the } \\
\text { membrane }(\mathrm{mm})\end{array}$ & $\begin{array}{l}\text { Water content as } \% \\
\text { weight of wet } \\
\text { membrane }\end{array}$ & $\begin{array}{l}\text { Porosity } \\
\text { membrane }\end{array}$ & $\begin{array}{l}\text { Swling of weightof wet } \\
\text { m-1 }\end{array}$ \\
M-2 & 0.2 & 2.0000 & 0.0005 & 0.04 \\
M-3 & 0.28 & 2.1762 & 0.0003 & 0.03 \\
M-4 & 0.3 & 2.15124 & 0.0003 & 0.03 \\
\hline
\end{tabular}

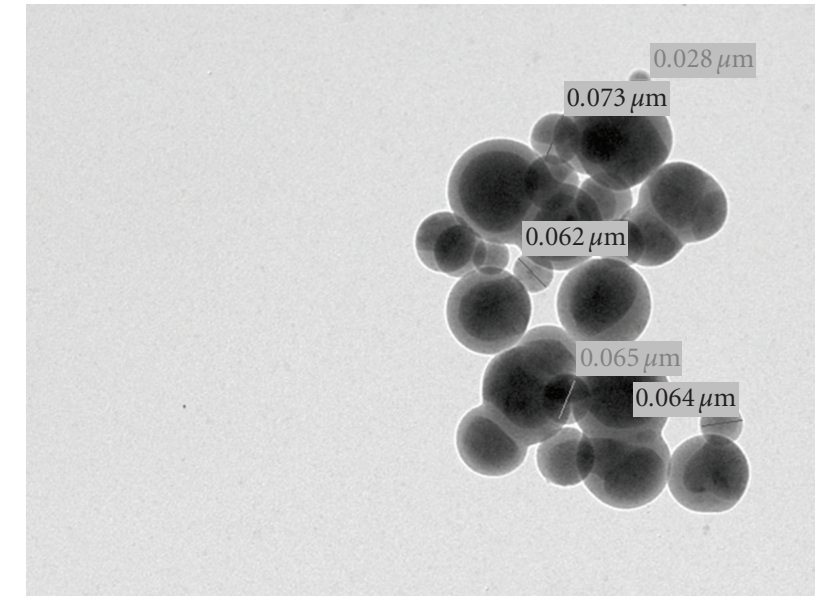

Figure 5: TEM Micrographs of Poly-o-anisidine Sn(IV) arsenophosphate composite cation exchanger at various magnifications.

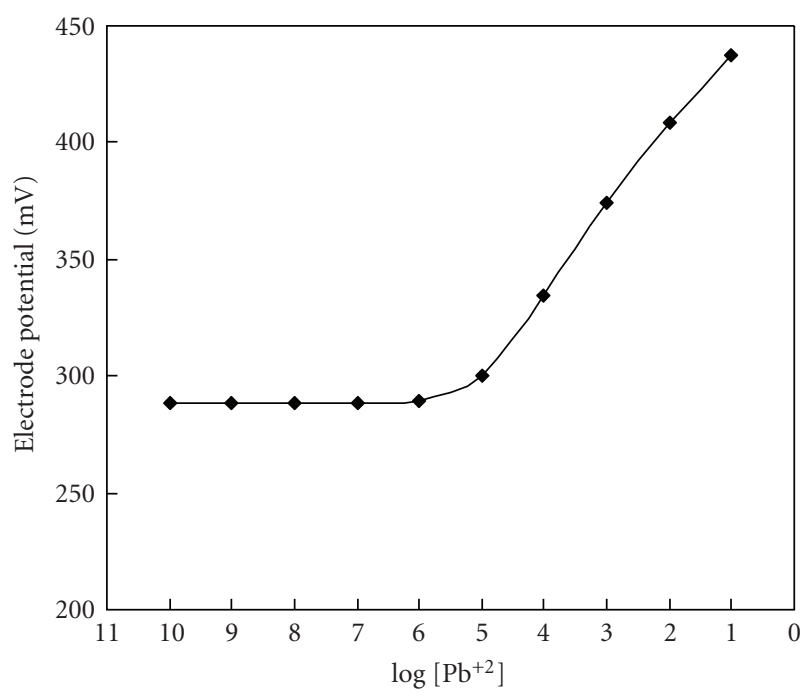

FIGURE 6: Calibration curve of poly-o-anisidine $\mathrm{Sn}(\mathrm{IV})$ arsenophosphate membrane electrode in aqueous solutions of $\mathrm{Pb}\left(\mathrm{NO}_{3}\right)_{2}$.

was observed that could be used for analytical applications as discussed elsewhere [20].

$\mathrm{pH}$ effects on the potential response of the electrode were measured for a fixed $\left(1 \times 10^{-2} \mathrm{molL}^{-1}\right)$ concentration of $\mathrm{Pb}^{2+}$ ions in different $\mathrm{pH}$ values. It is clear that electrode

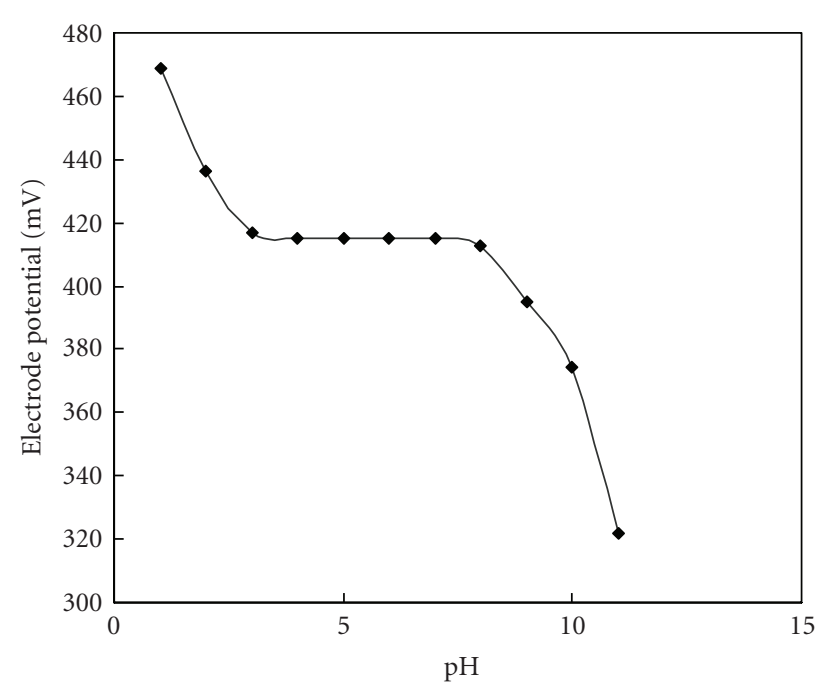

FIgURE 7: Effect of $\mathrm{pH}$ on the potential response of the poly-oanisidine $\mathrm{Sn}(\mathrm{IV})$ arsenophosphate membrane electrode at $1 \times 10^{-2}$ molL ${ }^{-1} \mathrm{~Pb}^{2+}$ concentration.

potential remains unchanged within the $\mathrm{pH}$ range 4.0-8.0 (Figure 7) known as working $\mathrm{pH}$ range for the electrode, below pH-4 the electrode is unable to work due to proton selectivity of the material, and above $\mathrm{pH}-8$ there is possibility of formation of $\mathrm{Pb}$ (II) hydroxides. Another important factor is the promptness of the response of the ion-selective electrode. The average response time is defined as the time required for the electrode to reach a stable potential after successive immersion of the electrode in different $\mathrm{Pb}^{2+}$ ion solutions, each having a 10 -fold difference in concentration. The response time in contact with $1 \times 10^{-2} \mathrm{molL}^{-1} \mathrm{~Pb}^{2+}$ ion solution was determined, and the results are shown in Figure 8. It is clear from the figure, that the response time of the membrane is $\sim 30$ seconds.

The selectivity coefficients, $K_{\mathrm{Pb}^{2+} \cdot \mathrm{M}}^{\mathrm{Por}}$ of various differing cations for the $\mathrm{Pb}$ (II) ion selective Poly-o-anisidine $\mathrm{Sn}(\mathrm{IV})$ arsenophosphate composite membrane electrode were determined, by the mixed solution method. The selectivity coefficient indicates the extent to which a foreign ion interferes with the response of the electrode towards its primary ions $\left(\mathrm{Pb}^{2+}\right)$. The selectivity coefficient of various cations for the $\mathrm{Pb}$ (II) ion-selective poly-o-anisidine $\mathrm{Sn}(\mathrm{IV})$ arsenophosphate membrane electrode are given in Table 5 which suggest that the membrane electrode is selective for $\mathrm{Pb}(\mathrm{II})$ in presence of interfering ions. 


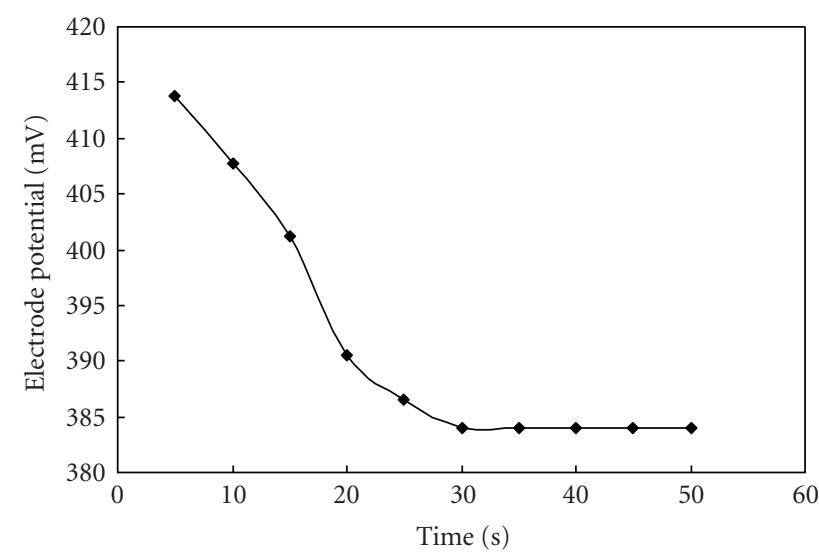

FIgURE 8: Time response curve of poly-o-anisidine $\mathrm{Sn}(\mathrm{IV})$ arsenophosphate membrane electrode.

TABLE 5: Selectivity coefficient of various interfering metal ions of poly-o-anisidine $\mathrm{Sn}(\mathrm{IV})$ arsenophosphate composite cation exchanger membrane.

\begin{tabular}{lc}
\hline Interfering metal ions & Selectivity coefficient \\
\hline $\mathrm{Zn}^{+2}$ & $2.4 \times 10^{-2}$ \\
$\mathrm{Cd}^{+2}$ & $2.2 \times 10^{-2}$ \\
$\mathrm{Cu}^{+2}$ & $2.3 \times 10^{-2}$ \\
$\mathrm{Mg}^{+2}$ & $2.0 \times 10^{-2}$ \\
$\mathrm{Co}^{+2}$ & $1.8 \times 10^{-1}$ \\
$\mathrm{Na}^{+}$ & $1.6 \times 10^{-1}$ \\
$K^{+}$ & $1.4 \times 10^{-1}$ \\
\hline
\end{tabular}

Nano- and picomolar range $\mathrm{pb}$ (II) sensitive ion-selective electrodes are reported as discussed by Sokalski et al., Ceresa et al., Ngeontae et al., Sutter et al., and Pergel et al. [21-25] in literature. However poly-o-anisidine Sn(IV) arsenophosphate is a micromolar range $\mathrm{Pb}$ (II) sensitive membrane electrode, but its quick response time ( $\sim 30$ Seconds), working $\mathrm{pH}$ range (4-8), and thermal stability suggest some important aspects of such class of materials.

\section{Conclusion}

Poly-o-anisidine Sn(IV) arsenophosphate is a nanocomposite ion exchange material exhibits that a good ion exchange capacity, thermal stability, and chemical resistivity. As shown in TEM photographs the particle sizes of the composite material are within the range of $0.073,0.065$, and $0.028 \mu \mathrm{m}$. Thus the material can be considered as nanocomposite material. This material was also utilized as an electroactive component for the preparation of ion-selective membrane electrode for the determination of $\mathrm{Pb}$ (II) ions in aqueous solution. The membrane electrode showed a working concentration range $1 \times 10^{-1} \mathrm{molL}^{-1}$ to $1 \times 10^{-6} \mathrm{molL}^{-1}$, response time $\sim 30$ seconds, $4-8 \mathrm{pH}$ range, and selectivity for $\mathrm{Pb}(\mathrm{II})$ in presence of other metal ions.

\section{Acknowledgments}

The authors are thankful to the Department of Applied Chemistry, Z. H. College of Engineering and Technology, A.M.U (Aligarh) for providing research facilities. Assistance provided by the I.I.T. Delhi and I.I.T. Roorkee to carry out some instrumental analysis and financial assistance provided by the University Grant Commission (UGC). India is also acknowledged.

\section{References}

[1] R. M. Laine, C. Sanchez, C. J. Brinker, and E. Giannelis, Eds., Organic/Inorganic Hybrid Materials, Proceedings of the Symposium on Materials Research Society, vol. 519, 1998.

[2] L. C. Klein, L. F. Francis, M. R. De Guire, and J. E. Mark, Eds., Organic/Inorganic Hybrid Materials II, Proceedings of the Symposium on Materials Research Society, vol. 576, 1999.

[3] P. Judeinstein and C. Sánchez, "Hybrid organic-inorganic materials: a land of multidisciplinarity," Journal of Materials Chemistry, vol. 6, no. 4, pp. 511-525, 1996.

[4] E. Ruiz-Hitzky, B. Casal, P. Aranda, and J. C. Galván, "Inorganic-organic nanocomposite materials based on macrocyclic compounds," Reviews in Inorganic Chemistry, vol. 21, no. 1-2, pp. 125-159, 2001.

[5] A. A. Khan, Inamuddin, and M. M. Alam, "Determination and separation of $\mathrm{Pb}^{2+}$ from aqueous solutions using a fibrous type organic-inorganic hybrid cation-exchange material: polypyrrole thorium(IV) phosphate," Reactive and Functional Polymers, vol. 63, no. 2, pp. 119-133, 2005.

[6] M. K. Ram, S. Carrara, S. Paddeu, and C. Nicolini, "Effect of annealing on physical properties of conducting poly(orthoanisidine) Langmuir-Blodgett films," Thin Solid Films, vol. 302, no. 1-2, pp. 89-97, 1997.

[7] R. Niwas, A. A. Khan, and K. G. Varshney, "Synthesis and ion exchange behaviour of polyaniline $\mathrm{Sn}(\mathrm{IV})$ arsenophosphate: a polymeric inorganic ion exchanger," Colloids and Surfaces A, vol. 150, no. 1-3, pp. 7-14, 1999.

[8] C. N. Reiliy, R. W. Schmidt, and F. S. Sadek, Journal of Chemical Education, vol. 36, p. 555, 1959.

[9] S. Amarchand, S. K. Menon, and Y. K. Agrawal, "Water hardness determination using $\mathrm{Mg}(\mathrm{II})$ ion selective electrode," Indian Journal of Chemical Technology, vol. 5, no. 2, pp. 99103, 1998.

[10] C. N. Reilley, R. W. Schmid, and F. S. Sadek, "Chelon approach to analysis (I) survey of theory and application," Journal of Chemical Education, vol. 36, no. 11, pp. 555-564, 1959.

[11] A. Craggs, G. J. Moody, and J. D. R. Thomas, "PVC matrix membrane ion-selective electrodes: construction and laboratory experiments," Journal of Chemical Education, vol. 51, no. 8, pp. 541-544, 1974.

[12] S. K. Srivastava, A. K. Jain, S. Agrawal, and R. P. Singh, "Studies with inorganic ion-exchange membranes," Talanta, vol. 25, no. 3, pp. 157-159, 1978.

[13] H. P. Gregor, H. Jagobson, R. C. Shair, and D. M. Wetstone, "Interpolymer ion-selective membranes. I. Preparation and characterization of polystyrenesulfonic acid-Dynel membranes," Journal of Physical Chemistry, vol. 61, no. 2, pp. 141147, 1957.

[14] E. P. Koval'chuk, N. V. Stratan, O. V. Reshetnyak, J. Błazejowski, and M. S. Whittingham, "Synthesis and properties of the polyanisidines," Solid State Ionics, vol. 141-142, pp. 217-224, 2001. 
[15] A. G. Mac Diarmid, R. B. Kaner, and T. A. Skotheim, Eds., Handbook of Conducting Polymers, vol. 1, Skothim Marcel Dekker, New York, NY, USA, 1986.

[16] D. K. Singh and S. Singh, "Synthesis, characterization and analytical applications of zirconium(IV) sulphosalicylophosphate," Indian Journal of Chemical Technology, vol. 11, no. 1, pp. 23-28, 2004.

[17] A. A. Khan and M. M. Alam, "Synthesis, characterization and analytical applications of a new and novel 'organicinorganic' composite material as a cation exchanger and $\mathrm{Cd}(\mathrm{II})$ ion-selective membrane electrode: polyaniline $\mathrm{Sn}(\mathrm{IV})$ tungstoarsenate," Reactive and Functional Polymers, vol. 55, no. 3, pp. 277-290, 2003.

[18] A. A. Khan, Inamuddin, and M. M. Alam, "Preparation, characterization and analytical applications of a new and novel electrically conducting fibrous type polymeric-inorganic composite material: polypyrrole Th(IV) phosphate used as a cation-exchanger and $\mathrm{Pb}(\mathrm{II})$ ion-selective membrane electrode," Materials Research Bulletin, vol. 40, no. 2, pp. 289-305, 2005.

[19] M. K. Amini, M. Mazloum, and A. A. Ensaf, Fresenius' Journal of Analytical Chemistry, vol. 364, p. 690, 1999.

[20] A. Demirel, A. Dogan, E. Canel, S. Memon, M. Yilmaz, and E. Kiliç, "Hydrogen ion-selective poly(vinyl chloride) membrane electrode based on a p-tert-butylcalix[4]arene-oxacrown-4," Talanta, vol. 62, no. 1, pp. 123-129, 2004.

[21] T. Sokalski, A. Ceresa, T. Zwickl, and E. Pretsch, "Large improvement of the lower detection limit of ion-selective polymer membrane electrodes," Journal of the American Chemical Society, vol. 119, no. 46, pp. 11347-11348, 1997.

[22] A. Ceresa, E. Bakker, B. Hattendorf, D. Gunther, and E. Pretsch, "Potentiometric polymeric membrane electrodes for measurement of environmental samples at trace levels: new requirements for selectivities and measuring protocols, and comparison with ICPMS," Analytical Chemistry, vol. 73, no. 2, pp. 343-351, 2001.

[23] E. Pergel, R. E. Gyurcsanyi, K. Toth, and E. Lindner, "Picomolar detection limits with current-polarized $\mathrm{Pb}^{2+}$ ion-selective membranes," Analytical Chemistry, vol. 73, no. 17, pp. 42494253, 2001.

[24] J. Sutter, E. Lindner, R. E. Gyurcsanyi, and E. Pretsch, "A polypyrrole-based solid-contact $\mathrm{Pb}^{2+}$-selective PVCmembrane electrode with a nanomolar detection limit," Analytical and Bioanalytical Chemistry, vol. 380, no. 1, pp. 7-14, 2004.

[25] W. Ngeontae, Y. Xu, C. Xu, et al., "Sensitivity and working range of backside calibration potentiometry," Analytical Chemistry, vol. 79, no. 22, pp. 8705-8711, 2007. 


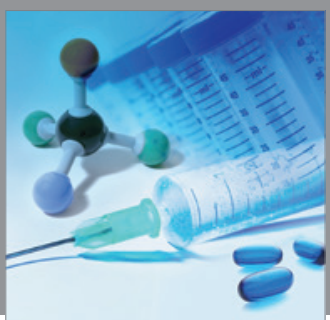

International Journal of

Medicinal Chemistry

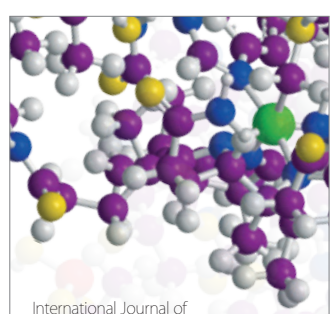

Carbohydrate Chemistry

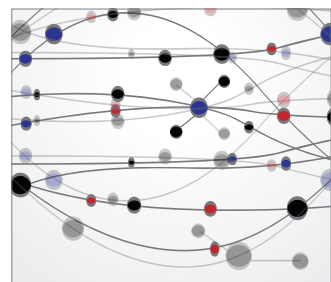

The Scientific World Journal
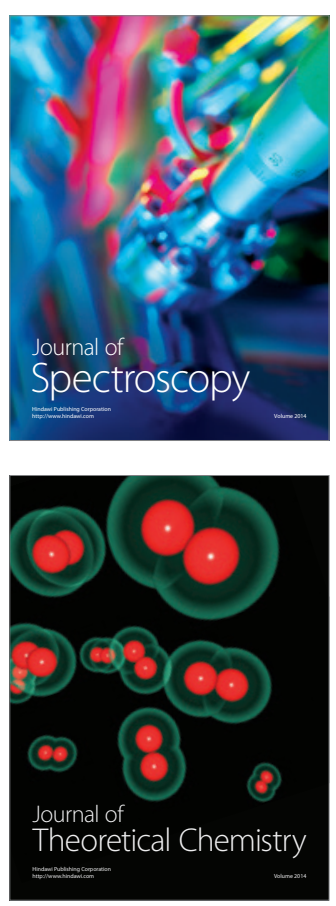
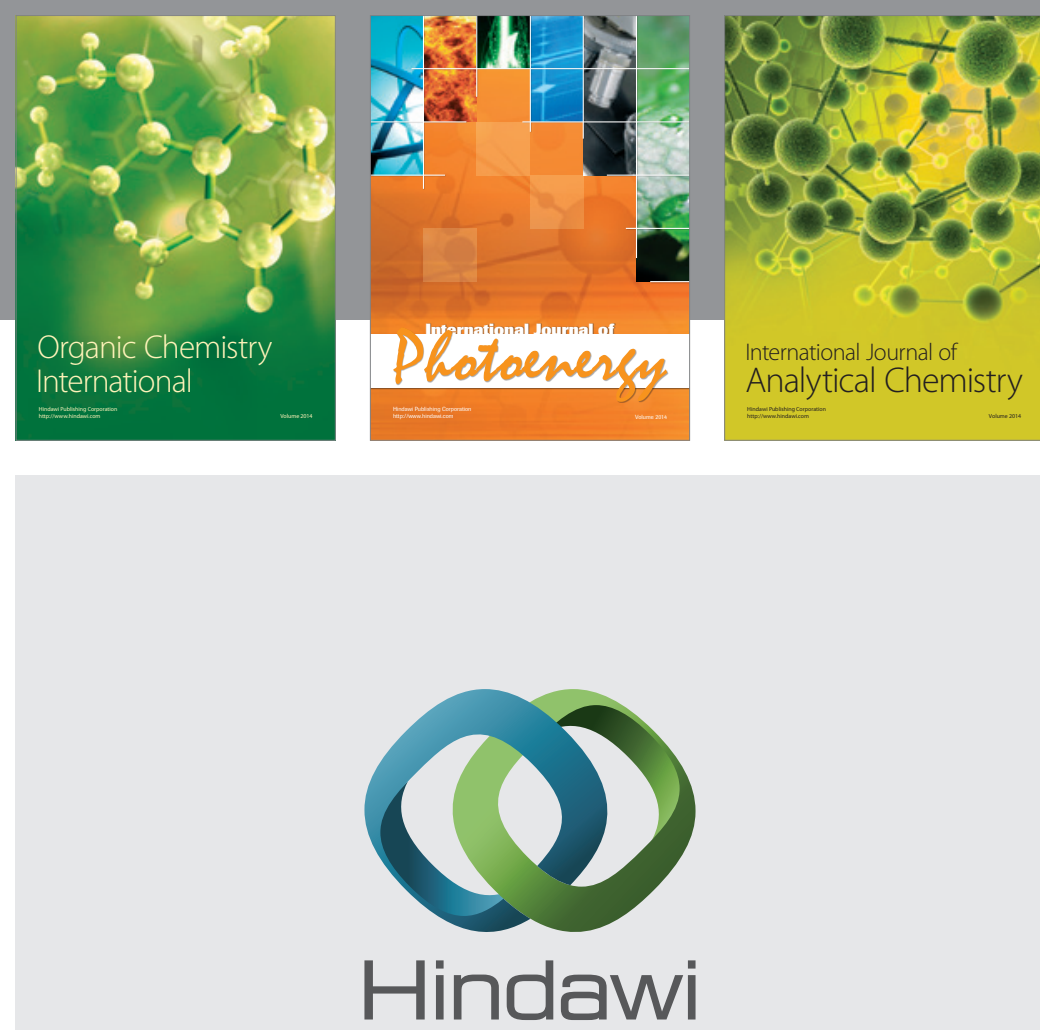

Submit your manuscripts at

http://www.hindawi.com
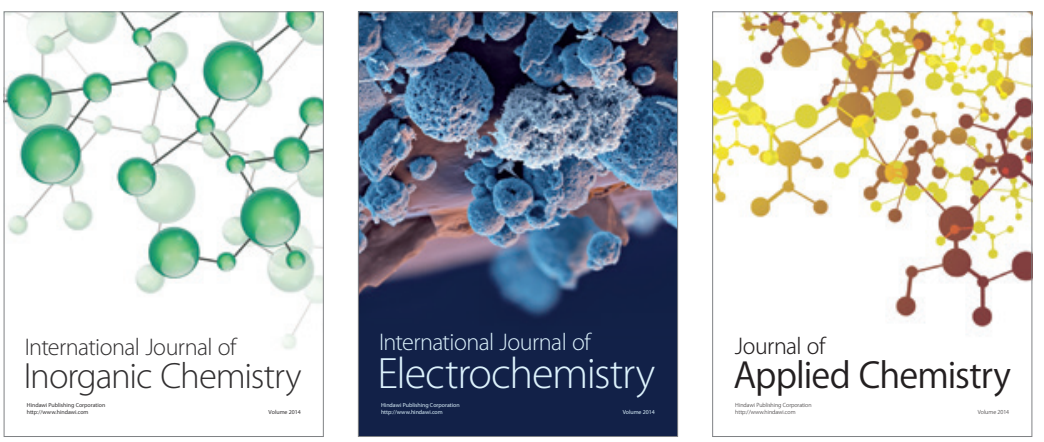

Journal of

Applied Chemistry
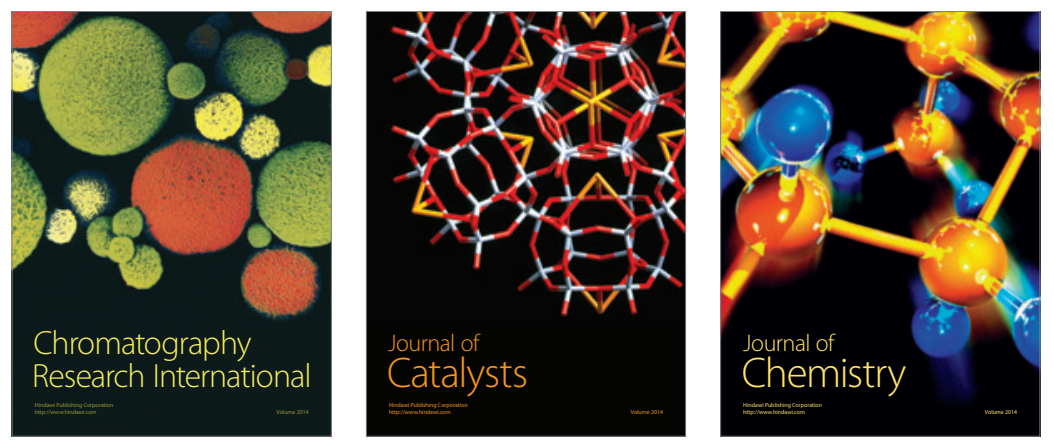
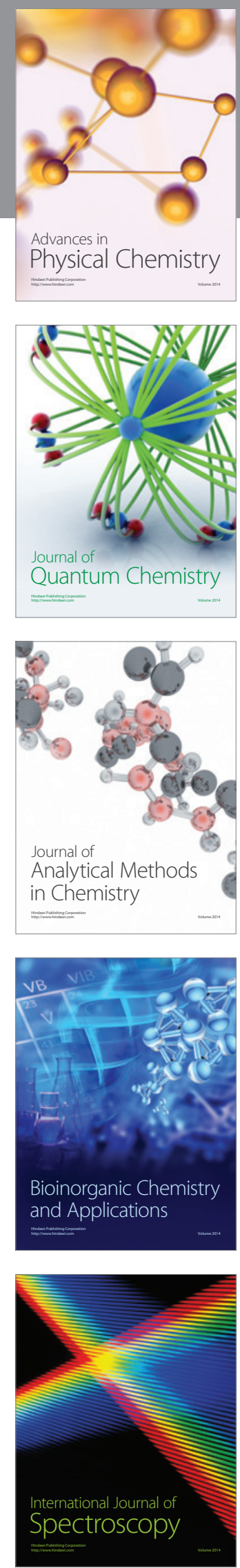